\title{
peluang dan tantangan orang aslu papua MENGHADAPI PERKEMBANGAN INDUSTRI DI KABUPATEN TELUK BINTUNI
}

\author{
THE OPPORTUNITIES AND CHALLENGES OF THE NATIVE PAPUANS \\ IN FACING THE INDUSTRIAL DEVELOPMENT IN TELUK BINTUNI REGENCY
}

\author{
Arie Januar \\ Balai Pelestarian Nilai Budaya Papua, \\ Jalan Isele Waena Kampung, Jayapura, Papua \\ E-mail: chaesar_arie@yahoo.com \\ Naskah Diterima: 13 Maret $2019 \quad$ Naskah Direvisi: 4 September $2019 \quad$ Naskah Disetujui :27 September 2019
}

DOI: 10.30959/patanjala.v11i3.511

\begin{abstract}
Abstrak
Industrialisasi dalam dekade terakhir telah menjadi isu yang sangat hangat di Indonesia, khususnya di Kabupaten Teluk Bintuni. Perkembangan industrialisasi yang terjadi di Bintuni telah menyebabkan perubahan pada aspek kehidupan orang asli, baik itu sosial, budaya, maupun ekonomi, sehingga untuk menghadapi sebuah perubahan mereka harus membuat strategi agar tetap eksis dalam melangkahi pembangunan. Tujuan dari penelitian ini adalah untuk mendeskripsikan tentang peluang dan tantangan orang asli Papua menghadapi perkembangan industri di Teluk Bintuni. Penelitian ini menggunakan pendekatan kualitatif. Pengunaan pendekatan ini bertujuan untuk menjelaskan fenomena yang ada secara detail dan mendalam dari proses perubahan sosial yang terjadi di Bintuni. Hasil dari penelitian ini menunjukkan bahwa perkembangan industrialisasi yang terjadi di Bintuni secara umum telah melampaui pelbagai aspek di dalam kehidupan orang asli. Perubahan ini dibuktikan dengan berkembangnya pola pikir, pola konsumsi, dan peralihan mata pencaharian dari petani dan nelayan ke sektor yang lebih luas.
\end{abstract}

Kata kunci: industri, orang asli Papua, Bintuni.

Abstract

Industrialization in the last decade has become a very salient issue in Indonesia, especially in the Teluk Bintuni Regency. The development of industrialization that occurred in Bintuni has caused changes in the lives of indigenous people, be it social, cultural, or economic aspects. So to face a change they must make a strategy to continue to exist in accordant with the development plan. The purpose of this study is to describe the opportunities and challenges of indigenous Papuans in facing industrial development in Bintuni Bay. This research uses a qualitative approach. The use of this approach aims to explain the phenomena in great detail. The results of this study indicate that the development of industrialization that occurred in Bintuni in general has influenced various aspects in the lives of indigenous people. This change is evidenced by the development of mindset, consumption patterns, and the shifting livelihoods from farmers and fishermen to the broader sector.

Keywords: industry, the native Papua, Bintuni.

\section{A. PENDAHULUAN}

Berbicara sejarah industrialisasi di Indonesia tidak terlepas dari kolonisasi bangsa-bangsa barat yang pernah datang di wilayah Indonesia. Menurut Basundoro
(2001: 133), cikal bakal dari kehadiran industri di Indonesia dapat dirunut melalui kehadiran industri perkebunan pada masa lalu. Secara umum, kehadiran industri perkebunan ini memang telah banyak 
menimbulkan permasalahan kemanusiaan di Indonesia, namun di sisi lain dengan adanya industri perkebunan justru telah banyak mengubah wajah perkembangan industri di Indonesia, terlebih setelah berlakunya Undang-Undang Agraria 1870. Dengan berlakunya UU Agraria tersebut, kran penanaman modal asing terus bertumbuh pesat (Ismono, 2013: 31-32). Hal ini terlihat dari mulai berdirinya sejumlah perusahaan swasta di Indonesia.

Perkembangan industri di Indonesia sampai dengan saat ini masih terus berkembang secara masif di pelbagai sektor, mulai dari industri pengolahan pangan, tekstil, pengolahan kayu, kimia, hingga pertambangan.

Teluk Bintuni merupakan salah satu kabupaten di Provinsi Papua Barat yang memiliki potensi sumber daya alam yang sangat berlimpah. Sumber daya alam ini meliputi hasil laut (perikanan), hasil hutan (kayu), dan pertambangan minyak serta gas.

Secara geografis wilayah teluk Bintuni terdiri atas kawasan hutan mangrove, luasnya \pm 225.367 hektar dan memiliki banyak manfaat bagi masyarakat. Salah satunya adalah sebagai sumber penghasilan dan kelangsungan hidup orang asli. Misalnya, keberadaan mangrove menjadi tempat berkembang biota laut, seperti kepiting, ikan, udang, dan lain sebagainya. Selain untuk pemenuhan kebutuhan hidup, keberadaan mangrove juga sangat bermanfaat bagi kehidupan flora atau tumbuhan, seperti jamur dan anggrek.

Dengan keanekaragaman sumber daya alam yang dimiliki, seperti flora, fauna, dan hasil tambang, teluk Bintuni sudah semakin banyak dilirik oleh perusahaan-perusahaan besar, baik skala nasional maupun multinasional yang ingin menanamkan modalnya. Ekspansi industri ini memang tidak dapat terhindarkan oleh orang asli ${ }^{1}$ Papua di Bintuni, terlebih

${ }^{1}$ Definisi orang asli menurut Undang-Undang No.21 Tahun 2001 tentang otonomi khusus pemerintah telah mencanangkan program pengembangan kawasan industri di teluk Bintuni sebagai salah satu proyek strategis nasional.

Saat ini sudah ada beberapa perusahaan besar yang sudah mengeksplorasi sumber daya alam di teluk Bintuni, seperti British Petroleum (BP Indonesia atau LNG Tangguh), Genting Oil, PT. Bintuni Utama Murni Wood industries, PT. Hastra Pasifik Papua, dan PT. Biak Veneer Jaya (Lihat Badan Pusat Statistik Kabupaten Teluk, 2018). Perusahaan-perusahaan ini bergerak dalam pelbagai sektor industri, mulai dari eksplorasi minyak, gas, hingga pengolahan kayu.

Kehadiran industri di Bintuni secara umum memang telah mendorong perekonomian di wilayahnya. Namun demikian, kehidupan orang asli yang bermata pencaharian sebagai nelayan, meramu, berburu, dan bertani mengalami dilema yang cukup besar. Pada satu sisi dengan keberadaan industri masyarakat diuntungkan, sebab dengan hadirnya industri arus ekonomi uang semakin tumbuh di wilayahnya. Sedangkan pada sisi lain, kehadiran industri menimbulkan kerugian bagi masyarakat, seperti pencemaran dan kerusakan lingkungan akibat aktivitas industri yang dilakukan oleh perusahaan.

Dengan pencemaran dan kerusakan yang terjadi, ekosistem alam yang menjadi tumpuan penghasilan orang asli semakin

bagi Provinsi Papua, adalah orang yang berasal dari rumpun ras melanesia yang terdiri dari suku-suku asli di Papua dan orang yang diterima dan diakui sebagai orang asli Papua oleh masyarakat adat Papua. Maksud orang asli yang diakui di dalam masyarakat merupakan orang asli yang secara utuh memang rumpun ras melanesia, namun ada juga orang asli yang berasal dari percampuran (peranakan), dan pendatang yang memang secara penuh memiliki persamaan pola pikir dalam memajukan kehidupan orang asli Papua, sehingga diakui menjadi anak adat oleh kepala suku 
berkurang. Merujuk pada pemikiran Kuntowijoyo (1991: 171-184), aktivitas industri merupakan bagian dari pendorong perubahan sosial yang paling dominan di dalam sebuah kehidupan bermasyarakat, hal ini karena kehadiran industri telah memunculkan masyarakat industri yang berbeda dari masyarakat agraris pada umumnya. Oleh karena itu, pembangunan potensi ekonomi menjadi daya tarik yang kuat dalam membangun kota, salah satunya adalah kawasan industri (Basundoro, 2001: 133-140).

Kawasan industri menurut UndangUndang Republik Indonesia Nomor 3 Tahun 2014 adalah kawasan tempat pemusatan kegiatan industri yang dilengkapi dengan sarana dan prasarana penunjang yang dikembangkan dan dikelola oleh perusahaan kawasan industri. Dengan demikian kehadiran industri sebagai suatu yang baru di masyarakat, menjadi salah satu pendorong ekonomi orang asli Papua di Bintuni. Hal ini karena dengan adanya aktivitas perusahaan, maka akan mendorong kesejahteraan masyarakat, mulai dari tersedianya lapangan pekerjaan, pendidikan, sarana kesehatan, pasar, dan lain sebagainya.

Namun demikian, kehadiran industri sebagai pendorong pembangunan menjadi sesuatu yang sangat dilematis. Industrialisasi yang sering kali digadanggadang sebagai solusi mengurangi kemiskinan, justru memunculkan permasalahan sosial dan budaya yang baru di masyarakat akibat perubahan sosial yang terjadi di wilayahnya (Suyanto, 2008: 163-173).

Menurut Soekanto (2001: 89) perubahan sosial merupakan perubahan pada lembaga-lembaga kemasyarakatan di dalam suatu masyarakat yang mempengaruhi sistem sosialnya termasuk nilai, sikap, dan perilaku. Hal ini senada dengan pendapat Soemardjan (1962: 379), di mana perubahan lembaga di dalam suatu masyarakat akan mempengaruhi segi-segi dalam sebuah struktur masyarakat lain. Artinya perubahan yang terjadi di dalam lembaga kemasyarakatan, akan pula diikuti dengan lembaga sosial yang lainnya.

Oleh karena itu, perubahan yang terjadi di kawasan teluk Bintuni tidak dapat terhindarkan. Hal ini karena proses industrialisasi telah mendorong berbagai aspek ke ranah yang lebih luas di dalam kehidupan orang asli, sehingga dengan modal yang mereka miliki sangat menentukan eksistensi mereka di wilayahnya.

Merujuk pada pemikiran di atas, rumusan masalah dalam tulisan ini adalah: (1) Bagaimana proses terjadinya industrialisasi di Teluk Bintuni, dan (2) Bagaimana peluang dan tantangan orang asli Papua di Bintuni. Berdasarkan dari rumusan masalah tersebut tujuan dari tulisan ini adalah untuk mendeskripsikan tentang proses awal terjadinya industrialisasi di Teluk Bintuni, hingga bagaimana peluang dan tantangan orang asli Bintuni di tengah perubahan sosial yang terjadi di wilayahnya.

Membahas tentang industrialisasi dan perubahan sosial memang sudah banyak dikaji di pelbagai daerah di Indonesia. Studi Rahman (2014: 1-6) misalnya, tentang perubahan pola perilaku sosial dan ekonomi buruh tani akibat industrialisasi. Dalam penelitiannya disimpulkan bahwa kehadiran industrialisasi telah banyak mempengaruhi kehidupan sosial ekonomi buruh tani di Desa Wadung, Kecamatan Jenu, Kabupaten Tuban. Hal ini dibuktikan dengan adanya perubahan pola pikir dan pola konsumsi masyarakat.

Perubahan ekonomi buruh tani di Desa Wadung setelah adanya industrialisasi, secara administratif banyak mengalami peningkatan di sektor ekonomi. Dengan adanya perubahan yang terjadi, maka pendapatan di kalangan masyarakat baik dari segi kompensasi penjualan lahan maupun kompensasi gaji tiap bulan semakin meningkat (Rahman, 2014: 5-6). Namun di lain sisi peluang kerja yang diberikan oleh pihak perusahaan terbatas, 
sehingga penyerapan tenaga kerja yang ada tidak maksimal.

Sementara itu menurut studi Suyanto (2008: 163-173), adanya industrialisasi di masyarakat lokal tidak serta merta berdampak baik di dalam komunitas masyarakat. Hal ini karena kehadiran industri juga menjadi ancaman bagi masyarakat asli, sebab apa yang dibutuhkan dengan apa yang diinginkan terkadang tidak sesuai dengan kebutuhan yang ada di masyarakat. Terlebih saat ini konsep industrialisasi kekinian sudah bergeser ke konsep industri 4.0 yang terkait dengan teknologi informasi. Oleh karena itu, strategi pembangunan yang berbasis teknologi sangat penting dalam upaya mengembangkan potensi sumber daya yang ada di Bintuni, agar dapat termanfaatkan secara baik di dalam kehidupan masyarakat.

Dari beberapa uraian di atas, terlihat bahwa kehadiran industri telah banyak memunculkan pelbagai fenomena atau peristiwa di masyarakat, baik secara sosial, ekonomi, maupun budaya. Untuk itu penelitian ini berusaha menggali secara lebih mendalam mengenai sejarah perkembangan industrialisasi, dari mulai munculnya industri hingga perkembangannya saat ini di dalam kehidupan masyarakat, khususnya di Indonesia bagian timur tepatnya di Kabupaten Teluk Bintuni.

Secara umum penelitian ini memiliki kesamaan dengan penelitianpenelitian sebelumnya, namun perbedaannya terletak pada lokasi yang masih jarang dilakukan yakni di Indonesia bagian timur. Geliat industrialisasi yang saat ini semakin gencar masuk di kawasan timur seperti Bintuni tidak diimbangi dengan sumber daya manusia yang ada, sehingga memunculkan ketimpangan sosial di kalangan orang asli. Alih-alih industri memiliki sumbangsih bagi kesejahteraan masyarakat justru mengikis tradisi dan kearifan lokal yang ada, sehingga orang asli sebagai pemilik wilayah merasa terasingkan di daerahnya sendiri. Namun demikian, hal ini tidak berlaku dengan orang asli yang memiliki modal sosial, ekonomi, dan budaya yang besar, mereka dapat berkompetisi secara baik dalam menangkap peluang ekonomi yang ada dengan strategi yang dimiliki.

\section{B. METODE PENELITIAN}

Pendekatan yang digunakan dalam tulisan ini adalah kualitatif. Pendekatan kualitatif digunakan untuk menjelaskan fenomena yang ada secara detail dan mendalam dari proses perubahan sosial yang terjadi di Bintuni. Penelitian ini juga berkategori deskriptif, yang mana fokus penelitian bertumpu pada proses dinamika yang terjadi di wilayah Bintuni dari awal munculnya industrialisasi hingga perkembangannya sekarang (Bungin, 2013: 33).

Metode pengumpulan data dalam penelitian ini adalah dengan melakukan wawancara sebagai metode utama dan observasi sebagai metode tambahan. Dalam hal ini, peneliti menggunakan wawancara berstruktur dengan jenis jawaban terbuka (open-ended). Metode ini digunakan agar peneliti dapat memperoleh informasi yang lebih luas dan kaya tentang subjek yang diteliti, sehingga peneliti dapat memahami subjek secara lebih mendalam. Data dan informasi yang dibutuhkan dalam penelitian ini terdiri dari data primer dan data sekunder.

Data primer diperoleh melalui wawancara mendalam, dan pengamatan terlibat. Informan yang menjadi sumber dalam penelitian ini adalah tokoh adat, tokoh pemuda, tokoh perempuan, dan orang asli Bintuni yang tinggal di Distrik Bintuni dan Babo. Kriteria informan ini diambil karena konteks perkembangan industri secara langsung telah mereka rasakan di wilayahnya, sehingga apa yang dilihat dapat mereka pahami secara baik. Untuk memperkuat argumentasi informan, penulis juga melakukan observasi wilayah untuk melihat kehidupan orang asli secara khusus, seperti mata pencaharian dan aktivitas sosial lainnya. Sedangkan data 
sekunder diperoleh dari studi kepustakaan yang berkaitan dengan objek penelitian.

\section{HASIL DAN BAHASAN}

1. Potret Kabupaten Teluk Bintuni

a. Kondisi Geografis Kabupaten Teluk Bintuni

Teluk Bintuni merupakan sebuah kabupaten yang terletak di Provinsi Papua Barat. Sebelum menjadi sebuah pemerintahan kabupaten, daerah ini merupakan sebuah distrik di bawah pemerintahan Kabupaten Manokwari. Baru pada tahun 2002, Teluk Bintuni mengalami pemekaran menjadi sebuah kabupaten berdasarkan Undang-Undang Nomor 22 Tahun 2002 tentang pembentukan Kabupaten di Provinsi Papua (Lembaran Negara Republik Indonesia Tahun 2002 Nomor 129). Dengan dibentuknya Kabupaten Teluk Bintuni sebagai sebuah institusi pemerintahan daerah, yang diharapkan dapat memberikan pelayanan umum yang cepat dan tepat guna mensejahterakan masyarakat.

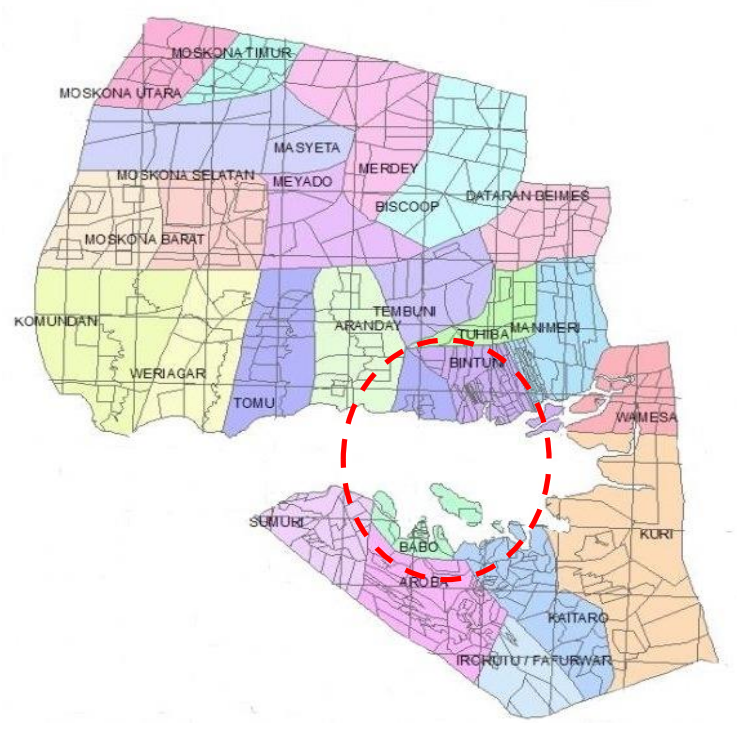

Gambar 1. Peta Kabupaten Teluk Bintuni Sumber: BPS Kabupaten Teluk Bintuni, 2018.

Persebaran penduduk di Teluk Bintuni terbagi menjadi beberapa wilayah, seperti pesisir, pulau, lembah, dataran, dan pegunungan. Luas wilayah Kabupaten
Teluk Bintuni $\pm 18.637,00 \mathrm{~km}^{2}$. Dari luas wilayah kabupaten, hampir seluruhnya merupakan wilayah payau atau hutan bakau yang berbatasan langsung dengan 5 kabupaten (Sorong Selatan, Manokwari, Fakfak, Kaimana, Teluk Wondama, dan Nabire) dan 1 Provinsi (Provinsi Papua). Berdasarkan Peraturan Bupati Teluk Bintuni Nomor 2 Tahun 2009, wilayah administrasi Kabupaten Teluk Bintuni terbagi menjadi 24 distrik, 115 desa difinitif, 145 desa persiapan, dan 2 kelurahan.

Orang asli Teluk Bintuni berasal dari tujuh suku besar, yakni suku Irarutu, Moskona, Sebyar, Kuri, Wamesa, Sough, dan Sumuri. Ketujuh suku ini merupakan orang asli yang sudah mendiami wilayah Bintuni sejak masa sebelum kolonial. Saat ini wilayah Bintuni sudah semakin beragam dalam komposisi jumlah penduduk. Hal ini karena semakin berkembangnya wilayah Bintuni, mengakibatkan munculnya masyarakat pendatang yang tinggal dan menetap di wilayah tersebut.

Jumlah penduduk Kabupaten Teluk Bintuni berdasarkan data Badan Pusat Statistik Kabupaten tahun 2017 tercatat sebanyak 60.400 jiwa tinggal di wilayah tersebut, dengan rincian 33.396 jiwa lakilaki dan 27.004 jiwa perempuan. Apabila dibandingkan dengan proyeksi jumlah penduduk tahun 2016, penduduk Kabupaten Teluk Bintuni mengalami peningkatan sebesar 2,03 persen, dengan masing-masing persentase pertumbuhan laki-laki sebesar 2,14 persen dan perempuan sebesar 1,91 persen. Sementara itu besarnya angka rasio jenis kelamin tahun 2016 antara laki-laki dan perempuan sebesar 123,67 (Badan Pusat Statistik Kabupaten Teluk, 2018).

Peningkatan komposisi jumlah penduduk yang terus bertambah setiap tahun di Teluk Bintuni belum diimbangi dengan persebaran penduduk yang merata di seluruh wilayahnya. Hal ini dapat terlihat dari sebagian besar penduduk masih terkonsentrasi atau terpusat di 
Distrik Bintuni yang merupakan pusat pemerintahan dan perekonomian.

\section{b. Potensi Sumber Daya Alam Kabupaten Teluk Bintuni}

Kabupaten Teluk Bintuni memiliki potensi alam yang sangat berlimpah, mulai dari sektor pertanian, kelautan, kehutanan, hingga pertambangan. Pada sektor pertanian misalnya dapat terlihat dari hasil bumi yang dihasilkan, seperti jagung, kacang tanah, kacang panjang, ubi kayu, ubi jalar, dan talas. Sektor pertanian merupakan mata pencaharian yang paling banyak dilakukan oleh Masyarakat setempat. Hal ini karena wilayah Bintuni yang subur menyebabkan tanamantanaman tersebut mudah untuk di tanam.

Sektor kedua potensi sumber daya alam yang ada di Bintuni adalah sektor kelautan. Sektor laut menjadi sumber yang sangat potensial karena secara kewilayahan Kabupaten Bintuni masih memiliki laut yang masih alami dengan hutan-hutan mangrove yang sangat luas. Salah satu hasil tangkapan laut yang menjadi andalan di masyarakat adalah udang dan kepiting. Jenis udang dan kepiting sangat banyak di perairan teluk Bintuni. Hal ini karena keberadaan hutan mangrove dan sungai yang besar membuat habitat udang dan kepiting sangat mudah untuk berkembang biak.

Bagi orang asli Papua yang tinggal di pesisir Teluk Bintuni, tradisi menangkap ikan seperti udang dan kepiting merupakan mata pencaharian utama mereka selain meramu. Pekerjaan ini pun sudah mereka lakukan sejak dahulu dengan mengunakan peralatan yang masih sangat sederhana, yaitu menggunakan rotan sebagai pengait. Hasil dari tangkapan yang mereka dapat diperuntukan untuk memenuhi kebutuhan hidup sehari-hari.

Selain potensi laut, Kabupaten Teluk Bintuni juga memiliki potensi dalam pemanfaatan hasil hutan. Hal ini terlihat dari banyaknya perusahaan kayu yang beroperasi. Dari data Dinas Kehutanan tahun 2014 terdapat delapan perusahaan kayu yang beroperasi di Kabupaten Teluk Bintuni (Badan Pusat Statistik Kabupaten Teluk Bintuni, 2018). Dalam kehidupan masyarakat kehadiran perusahaanperusahaan kayu di Teluk Bintuni sudah ada sejak lama dan secara tidak langsung telah banyak memberikan manfaat terutama dalam membuka akses penyerapan tenaga kerja.

Selain ketenagakerjaan, keberadaan perusahaan kayu di Teluk Bintuni juga telah membuka sebagian akses jalan antardistrik dan kampung. Apabila melihat aspek sektor pemanfaatan lahan, sektor kehutanan merupakan sektor yang paling besar dalam hal perizinan pemanfaatan hutan. Menurut kajian Paradise (2016), hampir semua indikatif wilayah suku terdapat izin pemanfaatan kayu dari hutan alam. Dari data yang ada teridentifikasi \pm 45 persen indikatif wilayah suku Bintuni terbebani izin pemanfaatan hutan dengan total kurang lebih 1,5 juta hektar.

Potensi alam lain yang banyak dikelola di Kabupaten Teluk Bintuni adalah sektor pertambangan minyak dan gas. Sektor pertambangan minyak dan gas di Indonesia saat ini sedang mengalami perkembangan di banyak tempat, termasuk Kabupaten Teluk Bintuni. Berdasarkan peta wilayah kerja WK Migas tahun 2016 Kementerian ESDM untuk lokasi Teluk Bintuni akan dilakukan perluasan yang mencakup hampir seluruh perairan yang ada di Teluk Bintuni. Rencana penambahan areal eksplorasi ini terbagi menjadi tiga blok, yaitu Blok Berau, Blok Muturi, dan Blok Arguni I. Ketiga blok tersebut direncanakan akan menjadi penawaran konsesi dengan pihak perusahaan pertambangan.

Saat ini perusahaan gas alam yang beroperasi di kawasan Teluk Bintuni adalah BP Indonesia atau LNG Tanggung. BP Indonesia atau LNG Tangguh mulai beroperasi di Teluk Bintuni sejak tahun 2002. Sebelum BP Indonesia masuk ke wilayah Teluk Bintuni, pada tahun 1973 sudah ada PT. Patrindo Persadamaju bekerjasama dengan Pertamina dan PT. 
Total yang mengeksploitasi areal bekas peninggalan Belanda (NNGPM). Kemudian Arco (Atlantic Richfield Corporation) menemukan cadangan gas alam cair (LNG) di sekitar Teluk Bintuni.

Dari hasil temuan tersebut, kawasan Teluk Bintuni pun dijadikan pusat pengeboran gas alam cair oleh BP Indonesia. Tujuan proyek LNG Tangguh sendiri adalah melakukan eksploitasi produksi gas alam dan melakukan kegiatan industri pengolahan gas menjadi LNG. Pada saat ini kegiatan proyek LNG sudah memasuki tahap produksi dengan menyerap jumlah tenaga kerja yang cukup banyak. Berdasarkan data Dinas Tenaga Kerja dan Transmigrasi Kabupaten Teluk Bintuni jumlah tenaga kerja yang tercatat di sektor migas ada sebanyak 3.843 orang yang terdiri dari 3.820 orang berasal dari tenaga kerja Indonesia dan 23 orang tenaga kerja asing.

\section{Kondisi Sosial Ekonomi Orang Asli Sebelum dan Setelah Masuknya Industri di Teluk Bintuni \\ a. Fase Awal Munculnya Industrialisasi di Teluk Bintuni}

Kehadiran industri di kawasan Bintuni bukanlah sesuatu yang baru terjadi di wilayah ini, sebab kawasan industri sudah bergeliat sejak masa kolonial. Penanda atau bukti fisik dari keberadaan industri pada masa kolonial terlihat dari beberapa peninggalan tambang minyak yang masih tersisa, seperti bangunan tangki minyak, gudang logistik, bangunan sekolah, rumah pegawai, sumur minyak, dan mesin pompa (Mene, 2011: 84-95). Konon peninggalan ini merupakan bangunan dari perusahaan minyak asal Belanda yang bernama Nederlandsch Nieuw Guinea Petroleum Maatschappij (NNGPM) pada tahun 1935.

Dengan keberadaan perusahaan minyak di kawasan Teluk Bintuni, pada akhirnya memunculkan bentuk perekonomian baru di dalam kehidupan masyarakat. Munculnya bentuk ekonomi baru ini ditandai dengan pembentukan pusat pelayanan pemerintahan dan perekonomian di kawasan Teluk Bintuni, di mana Stenkool menjadi pusat ibukota. Asal usul penamaan Stenkool sendiri diprakarsai oleh pemerintah Belanda. Pada saat itu kawasan ini merupakan tempat pemerintahan Belanda dalam mengeksplorasi sumber daya alam, seperti batu bara, minyak bumi, dan gas cair. Dengan kondisi yang ada, tidak mengherankan apabila Kabupaten Teluk Bintuni pada saat itu menjadi salah satu wilayah yang memiliki potensi sumber daya minyak dan gas cair yang cukup besar

Berbicara tentang perubahan sosial dan ekonomi yang terjadi pada orang asli Papua di Bintuni dapat ditelaah melalui beberapa fase pembangunan yang terjadi pada masa itu. Fase pertama pembangunan orang asli Papua di Bintuni terjadi pada masa kolonial, di mana Babo pada saat itu dijadikan pos pemerintahan di Teluk Bintuni pada 1920 (Rahman, Abd. dkk, 2008: 22). Kepopuleran Babo dibandingkan dengan daerah lain tidak terlepas dari fungsinya sebagai ibu kota pemerintahan dari salah satu resort di onderafdeeling Nieuw Guinea Barat (Rahman, Abd. dkk, 2008:23). Dengan dibentuknya pusat pemerintahan tersebut, Babo mengalami banyak perubahan secara fisik di wilayahnya. Ini dapat dilihat melalui bangunan-bangunan yang dibuat, seperti kompleks pemerintahan, perumahan pegawai, hingga transportasi.

Selain sebagai ibu kota pemerintahan, perkembangan Babo juga disebabkan oleh keberadaaan perusahaan minyak yang beroperasi di wilayah tersebut. Kehadiran perusahaan seperti Nederlandsch Nieuw Guinea Petroleum Maatschappij (NNGPM), secara langsung maupun tidak telah banyak mengubah kehidupan orang asli yang ada di daerah Teluk Bintuni, baik secara sosial kemasyarakat maupun perekonomian.

Menurut penuturan masyarakat, perekonomian lokal orang asli pada masa itu masih bersifat tradisional yang 
bertumpu pada aspek pertanian dan laut (seperti berladang, meramu, berburu, dan mencari ikan). Pekerjaan berladang merupakan pekerjaan pokok orang asli hingga saat ini. Tanaman yang dihasilkannya beragam, mulai dari ubi, petatas, hingga sayur mayur. Selain berladang, orang asli Papua juga melakukan pekerjaan sebagai peramu sagu. Aktivitas meramu tidak dilakukan oleh semua orang asli, melainkan hanya sebagian orang saja yang memiliki dusun sagu. Sedangkan aktivitas berburu merupakan pekerjaan laki-laki yang dilakukan di tengah hutan. Biasanya hasil yang diperoleh berupa babi hutan, rusa, dan tikus tanah. Aktivitas lain yang menjadi pekerjaan orang asli Papua di Bintuni adalah mencari ikan. Mata pencaharian ini merupakan pekerjaan yang banyak dilakukan oleh orang asli yang tinggal di pesisir pantai seperti di distrik Babo. Hasil yang mereka dapat beragam, mulai dari kepiting, udang, dan sejenis ikan laut yang banyak hidup di daerah hutan mangrove.

Dengan demikian apabila ditelusuri secara umum, kondisi perekonomian orang asli Bintuni pada masa itu masih bertumpu pada hasil bumi yang bersumber dari alam guna mempertahankan kehidupannya. Kondisi seperti ini sangat berbeda pada saat kehadiran perusahaan minyak masuk ke wilayah mereka, di mana pekerjaan orang asli mulai bergeser dari pekerjaan yang bersifat monoton (pekerjaan yang bersumber dari alam) menjadi pekerjaan yang lebih kompleks (buruh angkut barang, security, karyawan perusahaan).

Peralihan jenis pekerjaan disebabkan oleh beberapa hal, salah satunya perubahan fungsi lahan. Perubahan fungsi lahan yang tadinya digunakan sebagai lahan pertanian dan mencari ikan, beralih menjadi lahan industri yang mengarah pada kegiatan nonpertanian. Konvensi lahan yang terjadi di Teluk Bintuni merupakan suatu penanda terbentuknya kawasan industri, yang mana dengan munculnya industri yang ada mengakibatkan peralihan mata pencaharian di dalam kehidupan masyarakat, seperti jenis pekerjaan.

\section{b. Fase Setelah Masuknya Perusahaan NNGPM di Teluk Bintuni Tahun 1935}

Setelah masuknya perusahaan Nederlandsch Nieuw Guinea Petroleum Maatschappij (NNGPM) orang asli bekerja sebagai buruh angkut barang di pelabuhan dan mengangkut batang pohon yang ada di hutan untuk keperluan perumahan. Selain sebagai buruh angkut di pelabuhan, masyarakat asli juga ikut membantu perusahaan dalam membuka lahan hutan untuk pembangunan aktivitas pengeboran, sehingga mereka banyak meninggalkan kewajiban utamanya dalam mengelola sagu maupun pekerjaan mereka sebagai nelayan.

Pada masa lalu aktivitas ekonomi orang asli pun belum mengenal uang dan masih menggunakan cangkang kerang sebagai alat pembayaran. Seiring perkembangan yang terjadi dan diiringi dengan masuknya investor di wilayah mereka, berangsur-angsur mereka mulai mengenal uang sebagai alat pembayaran. Orang asli mulai mengenal uang dari hasil bekerja dengan perusahaan. Hal ini karena pada saat itu pengupahan dibayar dengan menggunakan uang sebagai alat resmi pembayaran. Dengan keberadaan uang, masyarakat dapat membeli apapun yang mereka inginkan, sehingga standar kehidupan mereka banyak mengalami peningkatan pada segi ekonomi.

Perkembangan pembangunan dan industrialisasi yang terjadi di Teluk Bintuni tidak melulu bersifat positif, melainkan juga berdampak negatif bagi kehidupan masyarakatnya. Hal ini terjadi karena industrialisasi di Bintuni secara langsung telah melahirkan marginalisasi di kalangan orang asli, kerusakan alam, dan ketidaksesuaian kebutuhan dengan yang diinginkan masyarakat (Suyanto, 2008: 163). Marginalisasi di kalangan orang asli disebabkan oleh kawasan tempat tinggal mereka yang semakin beragam. Kondisi 
seperti ini terlihat dari kehidupan orang asli yang tadinya bersifat tradisional, subsisten, dan komunal bertahap menjadi lebih modern.

Kehadiran industrialisasi yang diiringi dengan hadirnya pendatang merupakan faktor utama perubahan yang terjadi di Teluk Bintuni. Situasi seperti ini tidak dapat dipungkiri sebab kehadiran industri secara langsung maupun tidak telah banyak menarik pendatang untuk ikut berkontestasi menyerap tenaga kerja yang tersedia. Invasi pendatang yang bekerja di perusahaan mempunyai andil besar dalam mengubah struktur yang terjadi pada perekonomian orang asli. Pergeseran ini terlihat dari sistem nilai budaya masyarakat yang mulai berorientasi pada pertimbangan-pertimbangan yang bersifat rasional dalam memenuhi kebutuhan hidup.

Sistem nilai budaya merupakan konsep mengenai sesuatu yang hidup di dalam alam pikiran suatu manusia yang berisi tentang cara berpikir, tingkah laku, dan sikap mental (Herimanto, 12:19). Proses ini dilakukan dalam waktu yang cukup lama, sehingga menjadi kebiasaan yang melekat. Ada beberapa alasan mengapa pergeseran dan perubahan nilai budaya ini terjadi, salah satunya adalah munculnya aktivitas industri di wilayah mereka. Dengan adanya aktivitas industri yang semakin masif dan ditambah kehadiran pendatang menyebabkan berbagai perubahan dalam pelbagai aspek kehidupan. Perubahan ini meliputi gaya hidup, cara berpikir, dan mental masyarakat. Gaya hidup misalnya, saat ini banyak generasi muda yang memperlihatkan gaya kehidupan kota, seperti gaya hidup konsumtif. Menurut penuturan masyarakat setempat, anak-anak muda di zaman sekarang lebih senang mengenal kehidupan kota dibanding kehidupan yang ada di tanah kelahirannya. Contohnya bahasa, anak-anak muda sekarang lebih sering menggunakan bahasa Indonesia dan asing dibanding menggunakan bahasa ibu. Begitu pula dengan makanan, mereka lebih sering memakan nasi atau roti dibanding makanan tradisionalnya seperti papeda dan petatas.

Perubahan sosial yang terjadi di Teluk Bintuni secara umum sudah mengalami pergeseran yang cukup tajam di masyarakat. Namun di sisi lain, latar belakang pendidikan yang rendah dengan kualitas SDM yang terbatas dengan spesifikasi pekerjaan yang tersedia membuat orang asli kalah bersaing dengan masyarakat pendatang yang berasal Jawa, Makasar, dan Ambon, sehingga kontestasi pekerjaan membuat mereka tersisih dan sulit untuk beradaptasi dengan perubahan yang terjadi di lingkungannya. Namun demikian ada juga orang asli yang mampu beradaptasi dengan perubahan yang terjadi, misalnya dengan kehadiran perusahaan di lingkungan wilayahnya, mereka mampu menjadi pemasok makanan bagi para pekerja di perusahaan (seperti penyedia bahan sayur-sayuran, udang, kepiting, dan ikan).

\section{c. Fase Bergabungnya Papua dengan Negara Kesatuan Republik Indonesia Tahun 1963}

Fase kedua pembangunan terjadi pada masa era Papua bergabung dengan Negara Kesatuan Republik Indonesia. Dengan bergabungnya Papua dengan pemerintah Indonesia pada tanggal $1 \mathrm{Mei}$ 1963, maka secara resmi sistem pemerintahan Republik Indonesia mulai berlaku di Papua. Setelah bergabung dengan Indonesia, kondisi sosial dan budaya masyarakat Bintuni banyak mengalami perubahan, ini dapat dilihat dari jumlah komposisi penduduk yang tinggal di Bintuni. Selain peningkatan pada jumlah penduduk, sarana prasana pun mulai dibangun pemerintahan Indonesia, seperti pembangunan puskesmas dan balai pengobatan.

Pertumbuhan penduduk yang ditandai dengan masuknya pelbagai perusahaan di Teluk Bintuni mengakibatkan kondisi kemasyarakatan 
semakin beragam. Hal ini karena kehidupan masyarakat sudah mengalami percampuran antarorang asli dan pendatang. Kehadiran pendatang di wilayah Bintuni satu sisi memang dapat memacu pertumbuhan perekonomian masyarakat, namun di sisi lain keberadaan pendatang juga dapat menimbulkan persoalan baru di wilayahnya, seperti kesenjangan dan konflik ras.

Seperti yang sudah dijelaskan pada uraian sebelumnya, saat ini di kawasan Teluk Bintuni sudah terdapat beberapa perusahaan yang masuk dan beroperasi di wilayah tersebut, mulai dari perusahaan perkebunan (kelapa sawit), hutan (kayu), perikanan, hingga pertambangan (minyak dan gas). Arus investasi yang masuk begitu cepat ke Bintuni menyebabkan terjadinya perubahan fisik pada wilayahnya, seperti hutan kini sudah beralih menjadi pertambangan, perkebunan, dan lain-lain.

Pembangunan infrastruktur terus dikejar oleh pemerintah, baik berupa pembukaan akses jalan, pembuatan pelabuhan, pendidikan, hingga transportasi. Dengan keberadaan infrastruktur diharapkan dapat meningkatkan surplus ekonomi masyarakat setempat, sehingga dapat sejajar dengan wilayah lain yang ada di Indonesia.

Saat ini Kabupaten Bintuni masih masuk dalam 3 besar kabupaten termiskin di Papua Barat. Dari data BPS tahun 2017 angka kemiskinan di Bintuni mencapai 34,32 persen, dan pada tahun 2018 mengalami penurunan menjadi 31,30 persen (Badan Pusat Statistik Provinsi Papua Barat, 2018). Kondisi seperti ini sangat ironis, sebab di tengah masuknya perusahaan-perusahaan besar yang melakukan aktivitas eksplorasi sumber daya alam yang ada, justru membuat masyarakatnya terbelakang secara ekonomi.

Dalam konteks zona wilayah kemiskinan, sebenarnya di Kabupaten Teluk Bintuni tidak hanya dihuni oleh orang asli kelas menengah bawah, namun juga dihuni oleh kalangan orang asli menengah atas. Kurangnya komunikasi antarmasyarakat menengah atas dan bawah menyebabkan proses adaptasi dengan lingkungan mengalami hambatan. Hal ini karena modal sosial dan ekonomi yang dimiliki oleh orang asli tidak mampu mendorong pertumbuhan perekonomian masyarakat, terlebih hampir sebagian masyarakat merasa tidak memiliki keahlian memadai untuk berkompetisi mendapatkan pekerjaan (Ridho, 2016: 217-232).

Saat ini ekspektasi orang asli di Teluk Bintuni terkait pekerjaan hanya sebatas untuk memenuhi kebutuhan jangka pendek, seperti berdagang, buruh, dan pekerjaan non-keahlian (seperti menjual pinang dan sirih). Selain pekerjaan yang bersifat subsisten, orang asli juga ada yang bekerja di sektor formal, seperti pegawai negeri sipil dan karyawan di perusahaan milik pemerintah maupun swasta.

Seperti yang telah dijelaskan pada subbab sebelumnya, saat ini perusahaan yang beroperasi di Teluk Bintuni adalah BP Indonesia. BP Indonesia merupakan perusahaan kontraktor multinasional yang bergerak dalam bidang pengeboran minyak dan gas. Saat ini BP Indonesia sudah memasuki tahap produksi dan telah mengekspor hasilnya ke berbagai negara, seperti China dan Korea

Seperti halnya pada awal kehadiran perusahan Nieuw Guinea Petroleum Maatschappij (NNGPM) di Bintuni, keberadaan BP Indonesia juga diharapkan dapat menumbuhkan dan meningkatkan perekonomian masyarakat setempat. Hal ini karena dengan kehadiran perusahaan dapat memberikan lapangan pekerjaan baru bagi penduduk setempat pasca keruntuhan perusahaan NNGPM di Teluk Bintuni.

Selama beroperasi hampir \pm 17 tahun di Bintuni, BP Indonesia masih belum dapat meningkatkan kesejahteraan orang asli secara signifikan. Kondisi seperti ini dapat dilihat dari pekerjaan masyarakat yang masih bertumpu pada hasil bumi dan laut. Sekalipun ada yang dapat bekerja di BP Indonesia, mereka 
hanya sebagai buruh kasar atau satuan keamanan perusahaan, seperti pada masa era kolonial Belanda. Kondisi seperti ini memang tidak dapat dipungkiri, disebabkan kehadiran dunia industri yang mengharuskan orang asli untuk meningkatkan kualitas sumber daya manusia agar dapat terserap dan terlibat aktif dalam aktivitas industri. Sumber daya manusia sangat penting sebab apabila tidak dapat mengikuti perkembangan yang terjadi, mereka secara otomatis akan tersisihkan oleh pembangunan yang ada di wilayahnya.

Oleh karena itu, dengan masuknya pelbagai industri yang ada di wilayah Teluk Bintuni, kemampuan (skill individual) masyarakat harus ditingkatkan agar tidak kalah dengan pendatang. Begitu pula pendidikan, dengan tingkat pendidikan yang baik maka peluang orang asli dalam membangun komunitas dan wilayahnya akan semakin terbuka lebar. Hal tersebut perlu dilakukan agar modal sosial yang mereka miliki dapat membuat pelbagai peluang usaha, tanpa harus bergantung pada bantuan pemerintah maupun swasta.

Pendidikan merupakan faktor utama untuk mengangkat kesejahteraan orang asli di tengah semakin ketatnya kompetisi di dunia industri. Institusi pendidikan di Bintuni sebenarnya sudah ada sejak zaman kolonial, namun belum dirasakan maksimal oleh orang asli. Hal ini karena wilayah Bintuni pada masa lalu masih terisolasi, terutama dalam akses menuju sekolah. Pada masa pemerintahan Indonesia pendidikan sudah cukup mendapat perhatian besar. Situasi seperti ini dapat terlihat dari beberapa sekolahsekolah yang dibangun.

Berdasarkan data BPS Kabupaten Teluk Bintuni tahun 2017, dalam kurun 5 tahun terakhir jumlah sekolah di Teluk Bintuni terus mengalami peningkatan setiap tahunnya, ini dapat telihat dari data 2012 dengan jumlah 227 sekolah, lalu mengalami peningkatan di tahun 2016 menjadi 263 sekolah. Sementara itu lama sekolah penduduk menurut data BPS Provinsi Papua Barat sebesar 7,57 persen di atas rata-rata pemerintahan provinsi yakni sekitar 7.06 persen.

Sebelum dibangunnya sekolah oleh pemerintah Indonesia, sekolah yang berbasiskan yayasan keagamaan seperti Kristen Katolik sebenarnya sudah terlebih dahulu ada, namun keberadaannya belum terlalu maksimal. Hal ini karena keterbatasan sarana dan prasarana, sehingga pendidikan tidak berjalan secara baik. Peran sekolah keagamaan di Bintuni sangat besar, terutama dalam membentuk karakter masyarakat, seperti cara berperilaku, saling menghormati, dan saling tolong menolong.

Beranjak dari uraian di atas, pendidikan merupakan isu yang sangat penting dan selalu digaungkan oleh pemerintah saat ini. Hal ini karena pendidikan merupakan motor penggerak sebuah pembangunan sumber daya manusia. Oleh karena itu pendidikan menjadi suatu hal yang utama agar orang asli tidak kalah bersaing dengan pendatang dan pemodal-pemodal besar.

\section{Peluang dan Tantangan Orang Asli Papua di Teluk Bintuni}

Dari segi potensi sumber daya alam yang dimiliki, kawasan Teluk Bintuni mempunyai potensi yang cukup besar, terutama pada sektor hasil laut dan hutan. Menurut Bawole (2008) hutan yang terdapat di Bintuni dapat dikategorikan menjadi dua, yaitu hutan bakau dan hutan campuran. Hutan bakau merupakan hutan yang terdiri dari kawasan mangrove yang berada di perairan, sedangkan hutan campuran adalah hutan yang berada di kawasan laut dan darat.

Dengan situasi seperti ini tak heran apabila perekonomian orang asli sebagian besar adalah menjadi nelayan dan peramu. Mata pencaharian nelayan dan peramu merupakan pekerjaan utama orang asli hingga saat ini, sehingga hasil bumi menjadi tumpuan dalam pemenuhan kehidupan sehari-hari. Namun demikian 
dengan datangnya perusahaaan besar di kawasan mereka, jenis pekerjaan mereka pun mengalami peralihan menjadi tenaga kasar (buruh). Peralihan mata pencaharian orang asli merupakan bentuk langsung dari proses pembangunan, di mana kehadiran investor telah mendorong perubahan di pelbagai aspek pada kehidupan orang asli (Januar, 2016: 172). Situasi seperti ini terlihat dari kehidupan masyarakat yang dahulu pekerjaannya menggunakan peralatan tradisional dalam memenuhi kebutuhan hidup, bertahap menjadi lebih modern.

Pekerjaan sebagai nelayan misalnya, meskipun masih dilakukan secara sederhana menggunakan perahu tradisional, namun peralatan untuk menangkap ikan dan udang sudah mengalami perubahan yang cukup cepat, yaitu dengan menggunakan jala, jaring, dan pancing (Rumansara, 2003: 62). Selain peralatan menangkap, media penyimpanan ikan orang asli juga sudah menggunakan es sebagai media pendingin agar ikan terlihat lebih segar ketika akan dijual ke pasar.

Secara ekonomis hasil tangkapan orang asli pun sudah mengalami pergeseran, yang tadinya dikonsumsi untuk kebutuhan hidup sehari-hari, kini sudah mulai diperdagangkan di pasar-pasar. Kondisi seperti ini logis, sebab dengan adanya kemajuan di wilayah mereka, penetrasi uang sudah menyebar hingga ke wilayah terpencil, sehingga kebutuhan akan uang menjadi salah satu yang mutlak demi menjaga keberlangsungan hidup mereka di dalam komunitas.

Perkembangan

teknologi

penangkapan ikan pada masyarakat Bintuni telah mengalami banyak pergeseran berdasarkan deret waktu di dalam penggunaanya. Pergeseran teknologi dalam konteks penangkapan ikan memang tak dapat terhindarkan oleh orang asli yang tinggal di Teluk Bintuni. Hal ini disebabkan kemajuan teknologi akan terus bergerak hingga ke pelosok Bintuni. Oleh karena itu bagi orang asli yang memiliki modal besar akan menggembangkan peralatan yang ada guna memajukan usahanya. Sebaliknya bagi orang asli yang memiliki modal terbatas, maka akan bertahan dengan peralatan tradisional yang mereka miliki.

Berbicara keberlangsungan hidup terkait pula dengan pola adaptasi orang asli dalam mengarungi kehidupan. Oleh karena itu bertahan di dalam kawasan industri yang sedang berkembang di Teluk Bintuni memiliki tantangan tersendiri bagi setiap individu maupun komunitas, baik secara alami maupun terencana (Ridho, 2016: 225). Bertahan secara alami merupakan kemampuan masyarakat dalam memenuhi kebutuhan hidup sekadarnya. Maksudnya, kebutuhan pokok yang mereka dapat hanya sebatas cukup untuk makan sehari-hari. Sementara bertahan secara terencana orang asli menyadari dengan kondisi yang ada dapat memperbaiki kualitas kehidupan mereka ke depan agar setidaknya tetap hidup dengan standar yang layak (Allison, 2001).

Dari uraian di atas dapat dipahami bahwa orang asli yang memiliki kapasitas dan keahlian yang cukup, memiliki kesempatan yang lebih untuk tetap hidup layak, meskipun dalam situasi yang sangat sulit. Namun demikian, bagi orang asli yang memiliki modal terbatas, akan bertahan dengan situasi yang minim. Oleh karena itu sumber kekayaan alam yang ada harus dimanfaatkan secara baik, agar orang asli dapat bersaing dengan penduduk yang lain.

Dengan status sebagai orang asli, sebenarnya mereka mempunyai kewenangan yang cukup besar dalam memanfaatkan sumber daya yang ada di wilayahnya. Hal ini dapat terlihat dari penguasaan lahan yang dimiliki. Selain kesamaan identitas, hubungan jaringan dan solidaritas antarsesama orang asli juga sangat erat, sehingga dengan jaringan sosial yang ada itu, mereka dapat membentuk suatu komunitas yang kuat untuk melangkah menuju kehidupan yang lebih. Kekuatan orang asli berada pada budaya tradisi, adat istiadat, dan kearifan 
lokal. Dengan adanya kekuatan tersebut, ketahanan sosial di kalangan orang asli akan tetap terjaga di tengah gempuran industrialisasi yang terjadi di wilayah Bintuni.

Pada sisi lain kelemahan orang asli Papua terletak pada kemampuan atau keahlian yang masih minim (karena kemampuan mereka masih berlandaskan pada alam), pengetahuan dan pendidikan yang terbatas, teknologi yang digunakan sangat sederhana, modal yang terbatas, peran lembaga yang lemah, dan pemenuhan kebutuhan yang masih bersifat subsisten. Saat ini orang asli masih hanya sebatas penonton di wilayahnya. Apabila ditelusuri secara kultural, kemampuan lokal orang asli Papua di Bintuni cukup mumpuni terutama dalam hal menjaga ekosistem alam. Oleh karena itu, salah satu cara membangun kehidupan mereka adalah dengan melibatkan komponen kebudayaan yang ada di wilayahnya. Hal ini perlu dilakukan karena dengan berlandaskan pada budaya lokal, kemampuan mereka dapat terasah, sehingga mereka mampu bersaing dan berkompetisi dalam usaha mempertahankan komunitasnya.

Peluang orang asli dari kelebihan yang dimiliki sebagai orang asli adalah peningkatan perekonomian lokal, pengelolaan sumber daya alam secara mandiri, pemberdayaan pranata-pranata lokal yang ada, pengembangan kesejahteraan, dan tersedianya lapangan pekerjaan bagi masyarakat. Dari beberapa peluang yang dimiliki oleh orang asli sudah dimanfaatkan oleh sebagian masyarakat dalam bentuk kewirausahaan lokal. Dari hasil publikasi PT. SUBITU Inti Konsultan dalam bukunya tentang Direktori Pelaku Usaha Masyarakat Asli Kabupaten Bintuni sudah tercatat ada 15 pelaku usaha orang asli yang bergerak dalam pelbagai sektor usaha (Konsultan, 2016). Hal ini terlihat bahwa dengan masuknya industrialisasi di kawasan Bintuni sudah mulai direspon oleh orang asli, salah satunya dalam menangkap peluang ekonomi yang ada.
Ancaman akibat adanya industrialisasi di kawasan Bintuni adalah munculnya kecemburuan sosial di kalangan orang asli, resistensi sosial dan konflik, pergeseran gaya hidup, semakin memudarnya tradisi, adat istiadat dan kearifan lokal masyarakat, serta yang munculnya kesenjangan sosial akibat pembangunan yang tidak merata. Situasi ini logis terjadi sebab perhatian pelaku industri hanya memprioritaskan pada daerah yang terdampak langsung dari aktivitas industri yang dilakukan, sehingga orang asli lain yang jauh dari kawasan industri tidak merasakan kesejahteraan yang sama dengan saudara-saudara mereka yang terdampak langsung dari aktivitas industri.

Dari uraian di atas, ada beberapa upaya yang harus dilakukan baik oleh pemerintah maupun orang asli guna meningkatkan taraf hidup masyarakat. Pertama, dengan membentuk lembaga pelatihan kerja. Hal ini dilakukan agar orang asli dapat menyalurkan kemampuan sesuai dengan minat dan bakatnya. Kedua, melakukan pendampingan dan pembinaan bagi orang asli yang sudah menjalankan usaha seperti nelayan dan petani. Pendampingan ini dilakukan dengan cara pengenalan metode-metode baru maupun teknologi terkini yang dapat meningkatkan penghasilan mereka. Ketiga, peningkatan kualitas sumber daya manusia dan pemberdayaan. Peningkatan kualitas sumber daya manusia merupakan suatu keharusan bagi orang asli Papua jika tidak ingin terasingkan di wilayahnya. Menurut Sihabudin (2011: 18) sebagaimana ia mengutip pendapat Jim Ife menyatakan bahwa pemberdayaan ini dapat ditempuh dengan tiga strategi, (1) upaya pendidikan dan pembangkitan kesadaran, (2) upaya kebijakan dan perencanaan, dan (3) gerakan aksi sosial politik.

Pendidikan merupakan faktor yang paling esensial dalam pemberdayaan masyarakat. Hal ini karena dengan peningkatan pengetahuan melalui pendidikan maka orang asli akan mampu 
sekaligus mampu bersaing dengan masyarakat pendatang. Untuk itu dibutuhkan suatu kebijakan dan perencanaan yang matang dari semua pemangku kepentingan dalam upaya pemberdayaan orang asli, salah satunya dengan mendesain program bersama komunitas dengan menggunakan metode PRA (Participatory Rural Apprasial) (Sihabudin, 2011: 19).

Dengan metode tersebut, diharapkan orang asli dapat mendefinisikan kebutuhannya secara mandiri sesuai dengan keinginannya, sehingga mereka dapat menolong dirinya dan orang lain. Strategi terakhir adalah memperkuat atau membentuk aliansi masyarakat, seperti Lembaga Masyarakat Adat (LMA) atau LSM sebagai kekuatan masyarakat sipil untuk memengaruhi elit pemerintahan dalam membuat agenda atau wacana terkait peningkatan sumber daya manusia di Bintuni.

Keempat, terkait dengan peningkatan taraf hidup orang asli Bintuni adalah permodalan dan pemasaran. Permasalahan yang paling mendasar dari tidak berkembangnya perekonomian lokal di Bintuni adalah masalah permodalan. Keterbatasan modal membuat orang asli minim dalam membuat terobosan menangkap peluang ekonomi yang ada, sehingga kalah bersaing dengan pendatang. Selain itu, permasalahan kedua kurang berkembangnya perekonomian lokal adalah proses pemasaran hasil tangkapan dan hasil bumi orang asli yang terbatas. Oleh karena itu dibutuhkan peran serta pemerintah maupun swasta dalam mempermudah persyaratan permodalan bagi pelaku usaha lokal dalam mengembangkan usahanya. Adapun dalam konteks pemasaran, pemerintah dan swasta harus membuat sebuah wadah atau tempat yang dapat menampung hasil bumi orang asli agar mudah terjual.

Dasar penguatan dalam upaya pengembangan ini adalah adanya pengakuan dan penghargaan terhadap hakhak orang asli Papua di Bintuni dalam upaya memenuhi kebutuhan, terutama pekerjaan (Suyanto, 2008: 172). Hal perlu ini dilakukan agar orang asli mendapatkan keadilan yang layak seperti halnya masyarakat asli yang hidup di kawasan industri lain seperti di Jawa. Selanjutnya adalah penguatan kembali lembaga dan pranata lokal yang ada seperti LMA. Dengan peningkatan peran lembaga atau pranata lokal yang ada diharapkan dapat menjadi wadah atau forum keberpihakan bagi orang asli Papua di Bintuni. Wadah ini sangat penting sebab dengan adanya peran lembaga atau pranata lokal dapat mendorong transparansi pelaksanaan pembangunan, sehingga dengan pelibatan orang asli dalam proses pembangunan dapat sesuai dengan apa yang dibutuhkan.

Hal terakhir yang perlu diperhatikan dalam peningkatan taraf hidup orang asli Papua di Bintuni adalah penguatan budaya, tradisi, adat istiadat, dan kearifan lokal. Dengan penguatan unsur kebudayaan yang ada diharapkan dapat menjadi pedoman sekaligus aturan di masyarakat dalam melangkahi sebuah pembangunan yang terjadi di wilayahnya. Penguatan unsur kebudayaan perlu dilakukan karena dalam sebuah kebudayaan banyak mengandung pelbagai fungsi yang terkandung, seperti peraturan hidup, cara bertahan hidup, pendidikan, ekonomi, dan kesehatan.

Perhatian terhadap kebudayaan saat ini sudah mulai menjadi perhatian khusus oleh pemerintah, terutama setelah disahkannya Undang-Undang Nomor 5 Tahun 2017 Tentang Pemajuan Kebudayaan. Dengan adanya undangundang tersebut, maka fokus dalam sebuah pembangunan tidak hanya dalam ranah infrastruktur dan ekonomi, tetapi juga melibatkan unsur kebudayaan lokal yang ada. Dengan demikian upaya revitalisasi pelbagai nilai yang terkandung dalam sebuah kebudayaan, dapat membangun prinsip-prinsip hidup yang selaras dengan kehidupan modern.

Dari hasil telaah di atas dapat disimpulkan bahwa keberadaan industri di teluk Bintuni telah banyak memengaruhi 
perubahan besar dalam aspek sosial, ekonomi, dan budaya orang asli Papua. Hal tersebut dapat terlihat dari persaingan dalam menguasai sumber daya strategis, seperti ekonomi. Untuk mengatasi situasi itu maka orang asli harus memperkuat eksistensinya dengan cara meningkatkan kemampuan sumber daya manusia yang ada, dan memperkuat kelembagaan atau pranata lokal sebagai wadah pengaktualisasian diri masyarakat dalam upaya meraih peluang ekonomi.

Selain infrastruktur fisik, peran pemerintah tingkat pusat dan daerah juga memiliki kewajiban yang cukup besar, terutama dalam melakukan pendampingan dan monitoring pembangunan yang ada. Hal ini dilakukan karena dengan melakukan pendampingan dan monitoring, maka peningkatan kapasitas orang asli dalam menjajaki pembangunan dapat terealisasi secara baik. Implikasinya, pembangunan tak hanya berjalan pada infrastruktur fisik tetapi juga merambah pada tatanan sosial, seperti pendidikan, pelayanan kesehatan, dan kebudayaan.

\section{PENUTUP}

Dari hasil penelitian yang dilakukan dapat diketahui bahwa kehadiran industri di Teluk Bintuni sudah terjadi sejak masa kolonial Belanda. Hal ini terlihat dari adanya peninggalan-peninggalan dari perusahaan milik Belanda yang bernama Nederlandsch Nieuw Guinea Petroleum Maatschappij (NNGPM) pada tahun 1935. Industri ini muncul sebagai perusahaan minyak dan gas. Dalam perkembangannya, perusahaan Belanda ini mengalami pasang surut dan digantikan oleh PT. Patrindo Persada maju bekerjasama dengan Pertamina dan PT. Total dalam mengeksploitasi areal bekas peninggalan Belanda. Kemudian perusahaan asal Amerika Arco (Atlantic Richfield Corporation) menemukan cadangan gas alam cair (LNG) di sekitar Teluk Bintuni. Dari hasil temuan tersebut, masuklah BP Indonesia atau LNG Tangguh di kawasan Teluk Bintuni dan menjadikan wilayah itu sebagai pusat pengeboran gas alam cair hingga saat ini.

Selain perusahaan minyak dan gas, Teluk Bintuni juga terdapat industri perkebunan, seperti perusahaan kayu dan sawit. Dengan kehadiran industri di dalam kehidupan orang asli Papua di Bintuni, mereka dihadapkan pada dua kondisi. Satu sisi orang asli Papua diuntungkan dengan adanya industrialisasi di wilayahnya, dan satu sisi lagi orang asli dirugikan karena kesempatan mereka dalam mengelola lingkungan menjadi terbatas.

Dampak positif bagi orang asli dari adanya industrialisasi di wilayah Bintuni adalah terbukanya akses ekonomi, pendidikan, kesehatan, infrastruktur, dan informasi. Sedangkan dampak negatif bagi orang asli dari kehadiran industrialisasi adalah adanya pergeseran gaya hidup, resistensi sosial, dan konflik.

Dari uraian di atas terlihat bahwa dalam konteks industrialisasi secara langsung maupun tidak telah mengubah tatanan fisik maupun non-fisik dalam sebuah masyarakat. Bagi orang asli yang menerima perubahan dengan cepat, maka akan mampu beradaptasi dengan lingkungan, sedangkan bagi orang asli yang menerima perubahan secara lambat, mereka hanya dapat menjadi penonton di wilayahnya. Hal ini karena pelbagai faktor, salah satunya adalah mental psikologi, pendidikan, dan kemampuan beradaptasi yang minim dalam mengikuti arus perkembangan. Untuk itu dibutuhkan peran pemangku kepentingan dalam upaya mengembangkan kehidupan orang asli agar tidak tersisihkan dalam kontestasi pembangunan yang terjadi di Bintuni.

\section{DAFTAR SUMBER}

\section{Jurnal dan Laporan Penelitian}

Basundoro, Purnawan. "Industrialisasi, Perkembangan Kota, dan respon masyarakat: Studi Kasus Kota Gresik" dalam Jurnal Humaniora, Volume XII, No.2 Tahun 2001. 133-140.

Ismono. "Perkembangan Ekonomi Surabaya Setelah Penerapan Undang-Undang 
Agraria dan Politik Pintu Terbuka" dalam Jurnal Avatara, Vol .1 No.4 Tahun 2013. Hlm 30-33.

Januar, Arie. "Pola Praktik Kehidupan Komunitas Orang Asli Kukusan di Depok Jawa Barat" dalam Jurnal Patanjala, Vol.08 No.5 Juli 2016. Hlm 171-186.

Mene, Bau. "Peninggalan Kolonial di Kabupaten Teluk Bintuni" dalam Jurnal Рариа, Th. III No.2 September 2011. Hlm 81-96.

Rahman, Abd, D. 2008.

Sejarah Teluk Bintuni Awal Pemerintahan Kolonial Belanda di Papua Hingga Terbentuknya Pemerintahan Definitif Kabupaten Teluk Bintuni Pasca Pemekaran (1898-2006). Yogyakarta: Lanarka Kerjasama Lembaga Pengkajian dan Pengembangan Sosial Politik (LP2SP) FISIP Universitas Cenderawasih dengan Bappeda Kabupaten Teluk Bintuni.

Rahman, Fathor dan M Arief Affandi. "Perubahan Pola Perilaku Sosial dan Ekonomi Buruh Tani Akibat Industrialisasi" dalam Jurnal Paradigma, Vol.2 No.1 Tahun 2014. Hlm 1-6.

Ridho, Kholis. "Adaptasi Masyarakat Urban Terhadap Perubahan Sistem Mata Pencaharian Daerah Otonomi Baru Kota Tangerang Selatan" dalam Jurnal Socio Konsepsia, Vol.5 No.3. Hlm 217-234.

Rumansara, Enos H. "Kebudayaan Suku Sebyar di Teluk Bintuni Papua (Studi Kasus Desa Tomu)" dalam Jurnal Antropologi Papua, Vol.2 No.4 Tahun 2001. Hlm 47-65.

Suyanto, Bagong. "Industrialisasi MIGAS dan Eksistensi Masyarakat Lokal: Hasil Studi di Teluk Bintuni” dalam Jurnal Masyarakat, Kebudayaan, dan Politik, Th. XXI. No.2 April-Juni 2008. Hlm 163173.

\section{Buku}

Allison. Edward H, F. E. 2001.

The livelihoods approach and management of small-scale fisheries. Marine Policy.
Badan Pusat Statistik (BPS). 2018.

Teluk Bintuni Dalam Angka. Teluk Bintuni: Badan Pusat Statistik Kabupaten Teluk Bintuni.

Bawole R, Wanggai F, dkk. 2008.

Sumberdaya Perikanan Teluk Bintuni Papua; Potensi, Masalah Dan Upaya Pengelolaan. Jakarta: Departemen Kelautan dan Perikanan Indonesia.

Bungin, B. 2013.

Metode Penelitian Sosial dan Ekonomi. Jakarta: Kencana Prenada Media group.

Herimanto. 2011.

Ilmu Sosial dan Budaya Dasar. Jakarta: Bumi Aksara.

Konsultan, P. S. I. 2016.

Direktori Pelaku Usaha Masyarakat Asli Kabupaten Bintuni. Teluk Bintuni: PT. SUBITU Int Konsultan.

Kuntowijoyo. 1991.

Paradigma Islam: Interpretasi Untuk Aksi. Bandung: Mizan.

Sihabudin, A. 2011.

"Strategi Pemberdayaan Komunitas Adat Terasing 'Baduy': Suatu Upaya Menuju Perubahan" dalam Perubahan Sosial Sebuah Bunga Rampai. Serang: FISIP Untirta.

Soekanto, S. 2001.

Pokok-Pokok Sosiologi Hukum. Jakarta: Raja Grafindo.

Soemardjan, S. 1962. Social Changes in Yogyakarta. New York: Cornell University Press.

\section{Undang-undang}

Lembaran Negara Republik Indonesia Tahun 2002 Nomor 129.

Undang-Undang No.21 Tahun 2001 tentang Otonomi Khusus Bagi Provinsi Papua.

Undang-Undang Nomor 5 Tahun 2017 Tentang Pemajuan Kebudayaan.

Undang-Undang Republik Indonesia Nomor 3 Tahun 2014 Tentang Perindustrian. 